\title{
Do Conventional Comparative Cost Efficiency Analyses Adequately Value Nitrogen Loss Reduction Best Management Practices?
}

\author{
Shalamar D Armstrong, Richard T Roth and Corey G Lacey \\ Department of Agronomy, Purdue University, USA
}

Submission: November 17, 2017; Published: December 13, 2017

"Corresponding author: Shalamar D Armstrong, Department of Agronomy, Purdue University, Indiana, USA, Tel: 1-7654950256;

Email: sarmstro@purdue.edu

\begin{abstract}
Increasing public awareness of nitrogen $(\mathrm{N})$ loading to surface waters has resulted in increasing pressure for the adoption of Nitrogen Loss Reduction Best Management Practices (NLR BMPs). These practices are commonly evaluated by a comparative cost efficiency (CCE) that determines the ratio of implementation costs to $\mathrm{N}$ load reduction. This conventional methodology is essential for comparison of practices from a policy perspective. However, the CCE method does not consider potential short-term, on-farm benefits of in-field NLR BMPs. Therefore, it is the opinion of the authors that there is a need to advance the economic analysis of current NLR BMPs to better relate to the economics of adopting producers. In this paper we will discuss CCEs for several common NLR BMPs, argue that inclusion of cost-benefit analyses in CCE estimations of cover crops (CC) may alleviate producer financial concerns and increase practice adoption, and assert that there is a need for further research examining the economics of combinations of best management practices on field, watershed, and regional scales.
\end{abstract}

Keywords: Best management practices; Cover crops; Comparative cost efficiency; Conservation; Economics

Abbreviations: BMP: Best Management Practice; N: Nitrogen; CC: Cover Cropping; NLR: Nitrogen Loss Reduction; BMPs: Best Management Practices; CCE: Comparative Cost Efficiency; EOF: Edge of Field; IF: In Field; CEEC: Conservation Economic Efficiency Cost; USA: United States of America

\section{Introduction}

Growing awareness of nutrient contamination from row crop agriculture and its link to surface water contamination, such as the Gulf of Mexico Hypoxic Zone, has increased public pressure on agriculture to reduce our environmental footprint [1-3]. In agriculturally dominated watersheds, producers are implementing best management practices (BMPs) to prevent excessive nutrient losses, which contribute to public safety and environmental issues, through voluntary adoption or governmental cost share initiatives. The authors recognize that many nutrients can potentially pose an environmental concern. However, this paper will focus specifically on nitrogen (N) contamination of surface waters and agriculture BMPs designed to reduce $\mathrm{N}$ loading. Cover cropping (CC), one of the most widely recommend N Loss Reduction BMPs (NLR BMPs), has been shown to reduce $\mathrm{N}$ leaching and loss from agriculture fields [4-7]. Additionally, CC potentially provides multiple soil health benefits, beyond reducing surface water $\mathrm{N}$ contamination, that are not included in traditional comparative cost efficiency (CCE) calculations, the ratio of implementation costs to nitrogen load reduction. However, these demonstrated environmental and soil health benefits have not translated into producer adoption, thus only $2 \%$ of cropland acreage in the U.S. has adopted CC and only $4 \%$ of U.S. farmers have used cover crops [8].

This is evidence that there is a disconnect between cover crop research and producer adoption; which is exacerbated by the dearth of information that allows producers to understand the short-term value of CC. It has been established that BMPs are effective at reducing $\mathrm{N}$ loads; however, to drive voluntary adoption by producers, we must advance our understanding of how to determine the CCE of individual and systems of NLR BMPs. With this in mind, we intend to discuss CCEs for several common NLR BMPs, argue that inclusion of cost-benefit analyses in CCE estimations of CC may help producers value the sshortterm benefits of cc, and assert that there is a need for further research examining the economics of combinations of best management practices on field, watershed, and regional scales.

Fundamental Differences in Edge of Field and InField NLR BMPs

NLR BMPs can be categorized into two groups Edge-ofField (EOF) or In-Field (IF) practices. Constructed wetlands, denitrifying bioreactors, two-stage ditches, and controlled 
drainage are examples of EOF practices. In general, these practices reduce $\mathrm{N}$ loading by slowing water flow, creating anaerobic conditions, and facilitating denitrification. In contrast, IF BMPs are adaptive management strategies that reduce the actual losses of $\mathrm{N}$ from agriculture fields before it reaches the tile drainage system. Some examples of IF BMPs are cover cropping (CC) and 4R N management (right rate, right time, right source, and right place). In the literature, economic assessments of NLR BMPs have been conducted using CCE methodologies; estimates for several common BMPs are reported here (Table 1). In policy discussions, CCE values allow for the ranking of $\mathrm{N}$ load reduction efficiencies across multiple BMPs. Examples of this can be found in the Nutrient Loss Reduction Strategies of multiple Midwestern states $[9,10]$.

Table 1: Comparative cost efficiency values for nitrogen loss reduction best management practices commonly found in the Midwestern USA.

\begin{tabular}{|c|c|c|c|c|}
\hline \multicolumn{5}{|c|}{ Comparative Cost Efficiency, $\$ \mathrm{kgN}^{-1}$} \\
\hline NLR BMP* & Minimum & Maximum & Mean & References \\
\hline $\begin{array}{l}\text { Constructed } \\
\text { Wetland }\end{array}$ & 2.9 & 8.93 & 4.91 & $\begin{array}{c}\text { Roley, et al. [12], } \\
\text { Christianson [16], } \\
\text { Hyberg [19] }\end{array}$ \\
\hline $\begin{array}{l}\text { Denitrifying } \\
\text { Bioreactor }\end{array}$ & 2.1 & 4.87 & 3.49 & $\begin{array}{l}\text { Illinois Nutrient } \\
\text { Loss Reduction } \\
\text { Strategy [9], } \\
\text { Christianson [16] }\end{array}$ \\
\hline $\begin{array}{l}\text { Two-Stage } \\
\text { Ditch }\end{array}$ & & & 11.63 & Roley, et al. [12] \\
\hline $\begin{array}{l}\text { Controlled } \\
\text { Drainage }\end{array}$ & 2 & 2.71 & 2.36 & $\begin{array}{c}\text { Christianson [16], } \\
\text { Jaynes [17] }\end{array}$ \\
\hline $\begin{array}{c}\mathrm{N} \\
\text { Application } \\
\text { Timing }\end{array}$ & -14 & 6.99 & -3.51 & $\begin{array}{l}\text { Illinois Nutrient } \\
\text { Loss Reduction } \\
\text { Strategy [9], } \\
\text { Christianson [16] }\end{array}$ \\
\hline $\begin{array}{c}\mathrm{N} \\
\text { Application } \\
\text { Rate }\end{array}$ & -9.37 & -1.6 & -5.49 & $\begin{array}{c}\text { Illinois Nutrient } \\
\text { Loss Reduction } \\
\text { Strategy [9], } \\
\text { Christianson [16] }\end{array}$ \\
\hline Cover Crops & 2.22 & 11.06 & 6.64 & $\begin{array}{c}\text { Illinois Nutrient } \\
\text { Loss Reduction } \\
\text { Strategy [9], } \\
\text { Kladivko [11], } \\
\text { Roley, et al. [12], } \\
\text { Roth [13], Saleh } \\
\text { [18] }\end{array}$ \\
\hline
\end{tabular}

These CCE analyses only examine implementation costs to producers but do not consider any potential benefits. This is appropriate for most EOF practices that do not provide on-farm benefits beyond $\mathrm{N}$ loss reduction. However, an essential feature of IF practices are their potential to provide short-term benefits to producers such as erosion control, improved nutrient cycling, and potentially increased $\mathrm{N}$ utilization by cash crops. Therefore, it is the authors' opinion that the conventional CCE calculations underestimate the efficacy of CC and do not relate well to the economics of a producer.

\section{Inclusion of Cost-Benefit Analysis in Comparison Cost Efficiencies}

As indicated above, CC CCE analysis focuses only on the ratio of implementation costs (establishment, termination, and yield effects) to the $\mathrm{N}$ load reduction, regardless of potential on-farm benefits. In the literature, CCE values of US $\$ 2.22 \mathrm{kgN}^{-1}$ year ${ }^{-1}$ [11], US $\$ 6.24 / \mathrm{kgN} /$ year [13], US $\$ 7.08 \mathrm{kgN}^{-1}$ year $^{-1}$ [9], US $\$ 7.95$ $\mathrm{kgN}^{-1}$ year $^{-1}$ [12], and [18] have been reported that represent an average CCE of US $\$ 6.64 \mathrm{kgN}^{-1}$ year ${ }^{-1}$. The lack of methodology to include short-term, on-farm benefits in conventional CCE analyses result in less relevancy to producers because they do not reflect the impact of adoption on producers' profitability.

To address this concern, the literature has suggested a method for CCE that uses corrected implementation costs by performing cost-benefit analyses that include short-term, onfarm benefits (erosion control and improved $\mathrm{N}$ cycling); termed the Conservation Economic Efficiency Cost (CEEC) [13]. In comparison to the CCE values, they reported an average CC CEEC of US $\$ 1.09 \mathrm{kgN}^{-1} \mathrm{ha}^{-1}$ [13]. This model allows for a more accurate estimate of the cost of CC as an NLR BMP; which may alleviate producer financial concerns that are a barrier to BMP adoption. While this model is an initial step in improving our analysis of CC cost efficiency, more research is needed to provide valuation methods for other short-term benefits of CC across different regions and management systems.

\section{Systematic Best Management Practice Approach to N Reduction Goals on Field, Watershed, and Regional Scales}

In addition to improving our economic analysis of individual NLR BMPs, there is a need to understand how to use CEECs to asses a system of conservation practices (multiple NLR BMPs over a field, watershed, or regional scale). This has not been investigated in the literature. However, we do know from the literature that there is potential for combined BMPs to provide increased environmental benefits. For example, individual $\mathrm{N}$ load reductions of $11.8 \%$ and $35.6 \%$ have been observed for cover crops and controlled drainage, respectively. In comparison, the combination of these two practices resulted in an $\mathrm{N}$ load reduction of $47.5 \%$, which was greater than either of the individual treatments alone [14].

The systematic coupling of cover cropping and 4R management ( $\mathrm{N}$ application timing) has been investigated across a two-year corn-soybean rotation. Researchers reported an average $\mathrm{N}$ load increase of $17 \%$ by adjusting $\mathrm{N}$ application timing from fall to spring; a $3.7 \%$ decrease and $41.7 \%$ increase in the corn and soybean years, respectively [7]. Spring $\mathrm{N}$ application resulting in increased $\mathrm{N}$ load in the soybean year has been reported elsewhere in the literature [15-20]. However, when $\mathrm{N}$ application timing and CC are coupled, a 15.1\% decrease in the corn year and $32.8 \%$ reduction in the soybean year was observed 
in drainage system $\mathrm{N}$ loading [7]. A similar trend was observed where cover crops resulted in an average reduction in $\mathrm{N}$ load of $53.3 \%$ across both phases of a corn/soybean rotation [20]. These studies demonstrate that the combination of multiple BMPs has the potential to increase N load reductions across field, watershed, and regional scales.

However, there is a dearth of knowledge regarding how to value these conservation systems in a way that economically producers. Therefore, there is further need for research that examines the economics of conservation systems that include multiple BMPs.

\section{References}

1. Charles D (2017) The Gulf of Mexico's Dead Zone is the Biggest Ever Seen.

2. Hendy I (2017) Dead zone in the Gulf of Mexico is biggest ever.

3. Gulf of Mexico 'dead zone' is the largest ever measured.

4. Kaspar TC, Jaynes DB, Parkin TB, Moorman TB (2007) Rye Cover Crop and Gamagrass Strip Effects on NO3 Concentration and Load in Tile Drainage All rights reserved. No part of this periodical may be reproduced or transmitted in any form or by any means, electronic or mechanical, including photocopying, recording, or any information storage and retrieval system, without permission in writing from the publisher. J Environ Qual 36: 1503-1511.

5. Strock JS, Porter PM, Russelle MP (2004) Cover Cropping to Reduce Nitrate Loss through Subsurface Drainage in the Northern U.S. Corn Belt Names are necessary to report factually on available data. The use of the name by the USDA and the University of Minnesota implies no approval of the product to the exclusion of others that may also be suitable. J Environ Qual 33: 1010-1016.

6. Lacey C, Armstrong S (2015) The Efficacy of Winter Cover Crops to Stabilize Soil Inorganic Nitrogen after Fall-Applied Anhydrous Ammonia. J Environ Qual 44(2): 442-448.

7. Ruffatti MD (2016) Effect of Cover Crops and Nitrogen Application Timing on Nutrient Loading and Concentration through Subsurface Tile Drainage. Theses and Dissertations p. 632.

8. Wade T, Claassen RL, Wallander S (2015) Conservation-practice adoption rates vary widely by crop and region. United States Department of Agriculture, Economic Research Service.

9. Illinois Nutrient Loss Reduction Strategy (2015) Illinois Environmental
Protection Agency.

10. Iowa Nutrient Reduction Strategy (2016) Iowa Department of Natural Resources.

11. Kladivko EJ, Kaspar TC, Jaynes DB, Malone RW, Singer J, et al. (2014) Cover crops in the upper Midwestern United States: Potential adoption and reduction of nitrate leaching in the Mississippi River basin. Journal of Soil and Water Conservation 69(4): 279-291.

12. Roley SS, Tank JL, Tyndall JC, Witter JD (2016) How cost-effective are cover crops, wetlands, and two-stage ditches for $\mathrm{N}$ removal in the Mississippi River Basin? Water Resources and Economics 15: 43-56.

13. Roth RT, Ruffatti MD, ORourke PD, Armstrong SD (2018) A cost analysis approach to valuing cover crop environmental and nitrogen cycling benefits: A central Illinois on farm case study. Agricultural Systems 159: 69-77.

14. Drury CF, Tan CS, Welacky TW, Reynolds WD, Zhang TQ, et al. (2014) Reducing Nitrate Loss in Tile Drainage Water with Cover Crops and Water-Table Management Systems. J Environ Qual 43(2): 587-598.

15. Randall GW, Vetsch JA (2005) Nitrate losses in subsurface drainage from a corn-soybean rotation as affected by fall and spring application of nitrogen and nitrapyrin. Journal of Environmental Quality, 34(2): 590-597.

16. Christianson L, Tyndall J, Helmers M (2013) Financial comparison of seven nitrate reduction strategies for Midwestern agricultural drainage. Water Resour Econ 2(3): 30-56.

17. Jaynes DB, Thorp KR, James DE (2010) Potential water quality impact of drainage water management in the Midwest USA. In $9^{\text {th }}$ International Drainage Symposium held jointly with CIGR and CSBE/SCGAB Proceedings, 13-16 June 2010, Québec City Convention Centre, Quebec City, Canada. American Society of Agricultural and Biological Engineers p.1.

18. Saleh A, Osei E, Jaynes DB, Du B, Arnold JG (2007) Economic and environmental impacts of LSNT and cover crops for nitrate-nitrogen reduction in Walnut Creek watershed, Iowa, using FEM and enhanced SWAT models. Transactions of the ASABE 50(4): 1251-1259.

19. Hyberg S (2007) Economics of CREP/CRP treatment wetlands for the tile drained cropland in the Corn Belt.

20. Kaspar TC, Jaynes DB, Parkin TB, Moorman TB, Singer JW (2012) Effectiveness of oat and rye cover crops in reducing nitrate losses in drainage water. Agricultural Water Management 110: 25-33.
This work is licensed under Creative

Commons Attribution 4.0 License

DOI: 10.19080/ARTOAJ.2017.12.555861
Your next submission with Juniper Publishers will reach you the below assets

- Quality Editorial service

- Swift Peer Review

- Reprints availability

- E-prints Service

- Manuscript Podcast for convenient understanding

- Global attainment for your research

- Manuscript accessibility in different formats

( Pdf, E-pub, Full Text, Audio)

- Unceasing customer service

Track the below URL for one-step submission https://juniperpublishers.com/online-submission.php 